\title{
1
}

\section{Shaping Administrative Practice: The Institutional Habitus}

For me that is ok. [...] I mean, if someone uses a word like that who only started [working here] three months ago, I might ask: 'Hey, what does that mean for you?' But if [the decision] comes from someone whom I consider to be a valuable, serious, good employee, then I'll allow it, because I know, I can imagine what it means for them. ${ }^{1}$

So said Nora. We were talking about words like "plausible", "comprehensible", "logical" and "realistic". I had noticed that terms such as these occurred repeatedly in asylum decisions so I questioned her about them. Nora, not her real name but the name I have given her, is a state official working in the Swiss State Secretariat for Migration (SEM). She is the head of an asylum unit and, as such, one of her responsibilities is checking SEM decision-makers' asylum decisions before they are sent out to the applicants. In order for asylum seekers to be legally recognised as refugees and be granted asylum, their claims must be deemed (predominantly) credible by the decision-makers. It was these practices of assessing asylum seekers' credibility—or, more precisely, that of their claims - that Nora and I were discussing. From my observation of SEM asylum decision-makers at work as well as the analysis of case files, I knew decision-makers often used terms such as "plausible", "comprehensible", "logical" and "realistic" to substantiate their reasoning in credibility assessments. I asked Nora about the different criteria and in her reply quoted

\footnotetext{
${ }^{1}$ Nora, head of asylum unit, headquarters, interview transcript, my own translation.
} 
above, she claims that she "knows" or can at least "imagine what it means" for her experienced employees when they say that an asylum narrative is, for example, "logical" or "realistic". She thereby implies that she shares an understanding of these concepts with her employees as well as an understanding of what credible narratives look or rather feel like. It is this kind of shared implicit knowledge as well as shared understandings of what it means to do one's job well that are at the core of this book. To put it in more general terms, I am interested in how state officials working in administrative organisations - hence, the people who "apply" state policies and laws in their everyday work-come to think, feel, know and act in similar ways.

Studying what shapes and influences state officials' everyday practices is important, I argue, because it helps us understand the relatively stable outcomes of administrative practice that can be observed from the outside. Hence, this book is about the production of regularities in administrative work. Starting from Max Weber's ideal type of bureaucracy, the answer to the question what generates regularities of administrative practice seems simple: it is rule-bound conduct (see Weber 2013 [1978]: 220). ${ }^{2}$ However, as Weber's concept of the "ideal type" itself implies, in practice, administrative work functions differently. Caseworkers do more than "merely" follow rules as has been highlighted by much social science literature on administrative organisations (see, for instance, Alpes and Spire 2014: 267; Calavita 2005; Eule et al. 2019; Fuglerud 2004: 29; Heyman 1995, 2004, 2009; Liodden 2016: 68; Lipsky 2010; Maynard-Moody and Musheno 2003). Building on this broad body of literature, I argue that we must therefore also pay attention to other factors-beyond written (legal) rules - that shape administrative caseworkers' everyday practices. Such factors include organisational socialisation, the ideological environments in which administrations and their officials work, professional norms and values, embodied knowledge and routines as well as decisional pragmatism (see also Alpes and Spire 2014; Dahlvik 2018; Eckert 2020; Eule et al. 2019; Fassin and Kobelinsky 2012; Heyman 2004; Johannesson 2017; Jubany 2017; Liodden 2016; Miaz 2017; Mountz 2010; Poertner 2018; Probst 2012). However, at the same time, we should not underestimate the role that rules play in guiding administrative work. Rules are, as Hendrik Wagenaar writes, "simultaneously part of the problem as it

\footnotetext{
${ }^{2}$ The terms "bureaucracy" and "bureaucrats" carry negative connotations. They are often associated with "red tape" and "officialism" and used as criticism (see Downs 1967: 1; Eckert 2020: 7; Poertner 2017: 12). In this book, I mostly use the terms "administration" and "office". However, when referring to literature which uses the terms "bureaucracy" and "bureaucrats", I employ the same terminology. For the people working in administrations, I use the terms "caseworkers", "decision-makers" and "officials" interchangeably.
} 
presents itself [to caseworkers], and part of the solution. [...] [They] structure the situation [...] [and] suggest what is possible and feasible" (2004: 650). Yet, as Wagenaar then goes on to claim, "for the rule to be able to act as a rule it is important that [caseworkers] have a grasp of what the point is of using that rule in a particular situation" (ibid.). Hence, without caseworkers' understanding of and knowledge about these rules, they are socially meaningless. It is only through officials' mobilisation and interpretation of rules when putting them to use that they "materialise in practice" (Eule et al. 2019: 90; see also Moore 1978; Sarat 2007). Without officials' grasp of the rules, the latter would therefore, in the words of Hendrik Wagenaar, merely be a "dead letter" (2004: 650). This reflects the distinction made by sociolegal scholars between "law in the books and law as practice" (Eule et al. 2019: 90). My main concern in this book is, therefore, how administrative caseworkers come to understand, mobilise, interpret and thereby shape legal rules in the course of their everyday work. I show how these practices of interpreting and "making" law are, on the one hand, shaped and structured by the organisational environment the officials work in and are, on the other hand, also constitutive of the latter.

Empirically, my analysis is based on a specific case study: asylum decisionmaking in Switzerland. Thus, I study the everyday practices of decisionmakers working in the asylum divisions of the SEM, which is the state administration in charge of taking first-instance asylum decisions in Switzerland. Caseworkers at the SEM decide whether asylum claims are credible or not; whether asylum seekers are eligible for asylum or refugee status andin the case of negative asylum decisions-whether or not applicants should be granted temporary protection. In my ethnography of everyday administrative practices in the SEM, I deal with the following questions: What are dominant patterns of decision-making? How are these patterns generated? How are they reproduced through everyday practice? And, most importantly, how do certain patterns of decision-making become the routine or self-evident ones for decision-makers to follow? I am thereby particularly interested in what Hendrik Wagenaar calls "the taken-for-granted routines: the almost unthinking actions, tacit knowledge, fleeting interactions, practical judgements, self-evident understanding and background knowledge, shared meanings, and personal feelings that constitute the core of administrative work" (Wagenaar 2004: 643).

Studying caseworkers' grasp of legal rules-how they mobilise and interpret them in their everyday work-is crucial because in much socio-legal research as well as in so-called street-level bureaucracy studies, laws and policies are understood as something that must necessarily always be interpreted when being fitted with specific situations or cases (Eule et al. 2019: 101; 
Hawkins 1992: 11; Heyman 2004: 493; Poertner 2018: 10-11; Wagenaar 2004: 651). Laws and policies are not simply "applied" or "implemented" by the caseworkers, but rather become "shaped and mediated" (Wedel et al. 2005: 34) and are "(co-)produced" (Poertner 2018: 10) through officials' everyday practices (see von Benda-Beckmann 1991; Brodkin 2011: 253-254; Eckert, Behrens, and Dafinger 2012; Eule 2014; Shore and Wright 2011). Hence, if we want to understand how asylum law and policy work, we must study caseworkers' everyday decision-making practices. Beyond this, studying caseworkers' everyday practices is also crucial for understanding the workings of the state, since it allows us to analyse the "everyday production of stateness" (Eckert, Biner, Donahoe, and Strümpell 2012: 15, see also Beek 2016). The state is thereby comprehended not as a monolithic entity, but rather as something that is produced through the everyday practices of state officials as well as through people's imaginations of the state (Bierschenk and Olivier de Sardan 2014; Eckert, Biner, Donahoe, and Strümpell 2012; Fassin 2015; Gupta 1995; Mountz 2010; Sharma and Gupta 2006).

This idea that we must study "what lower-level officials do in the name of the state" (Gupta 1995: 376) is at the core of numerous in-depth studies of asylum and migration administrations and courts (see, for instance, Alpes and Spire 2014; Calavita 1992; Dahlvik 2018; Eule 2014; Eule et al. 2019; Johannesson 2017; Jubany 2017; Kobelinsky 2015; Liodden 2016; Miaz 2017; Mountz 2010; Poertner 2018; Probst 2012; Scheffer 2001; Tomkinson 2018; see also the edited volumes by Gill and Good 2019 and Lahusen and Schneider 2017). The authors all study asylum and migration case- and decision-making from a bottom-up perspective, describing caseworkers' everyday practices in great detail. Furthermore, several of them share my interest in how everyday administrative practices become structured. They focus on different aspects shaping decision-makers' everyday practices, such as organisational socialisation (Dahlvik 2018; Heyman 2004; Jubany 2017; Miaz 2017; Probst 2012), regulatory constraints (Dahlvik 2018; Miaz 2017), collective knowledge and embodied know-how (Dahlvik 2018; Jubany 2017; Liodden 2016; Poertner 2018), pragmatic considerations (Eule et al. 2019; Poertner 2018), professional role perceptions (Johannesson 2017; Jubany 2017), accountability towards peers, authoritative bodies and the general public (Heyman 2004; Johannesson 2017; Liodden 2016; Miaz 2017; Mountz 2010) as well as the broader political environment in which the organisations are embedded (Alpes and Spire 2014; Dahlvik 2018; Fassin and Kobelinsky 2012; Jubany 2017; Mountz 2010).

My book builds on these studies. I argue that it is important to not only study what decision-makers do, but to also analyse what makes them do 
what they do, in order not to fall into the reductionist trap of bottom-up approaches to the state that Didier Fassin cautions against. Fassin argues that we should not treat practices of state-making as taking place in a vacuum, since state "agents are confronted with explicit and implicit expectations formulated in discourses, laws and rules while keeping sizable space to manoeuvre in the concrete management of situations and individuals" (2015: 4). If we want to understand how the state and policies work in practice, we must, therefore, pay attention to the regulatory constraints and the ideological environments under and in which these practices take place (ibid.: 6; see also Eckert 2020). My study does this by developing the concept of the institutional habitus, building on practice theory, and particularly the work of Pierre Bourdieu. I understand the institutional habitus as the schemes of thinking, acting, feeling and desiring that arise from caseworkers belonging to and working in the SEM (see Bourdieu 1976; Terdiman 1987: 811).

However, before I describe my conceptualisation of the institutional habitus in detail, I will outline two main discussions to which this book makes a contribution through its focus on the shaping and structuring of everyday practices. The first discussion is concerned with the role of socalled discretionary practices in processes of bureaucratic decision-making. The second relates to the widespread critique of credibility assessments in asylum procedures as being "arbitrary" and based on "subjective beliefs".

\section{The Shaping of Discretion}

Discretion is at the centre of much of the literature on street-level bureaucracies and I engage with these discussions for two main reasons. Firstly, I challenge the binary distinction made both explicitly and implicitly in some of the literature between "law", on the one hand, and "discretion", on the other. This critique is, of course, not new (see, for instance, Eule et al. 2019: 86-89; Pratt 1999; Pratt and Sossin 2009). However, like Tobias Eule et al., when presenting my research to both academic and non-academic audiences, I have "time and again encountered striking adherence to the idea of a regime ruled by law" (2019: 83). People are often surprised and even outraged by the fact that decision-makers interpret—rather than just "apply"—rules when putting them to use in specific situations. Therefore, it seems crucial to continue stressing the important role that discretionary practices play in administrative decision-making. Discretion is what makes law work (see Eule et al. 2019: 86, 105). It necessarily forms part of law in practice. 
Secondly, I argue against the individualist assumption about discretionary freedom inherent in some of the street-level bureaucracy literature (see also Eckert 2020). This critique, again, is not entirely new; several scholars working on asylum and migration administrations have precisely pointed to the importance of studying how discretionary practices are shaped (see Brodkin 2012: 942; Dahlvik 2018; Hawkins 1992; Liodden 2016). Nevertheless, because much of the focus has been on the divergences of asylum decision-making practices rather than on how regularities in administrative practice are produced, I contend that the structuring of discretion has so far received too little attention.

Since the 1960s, studies of administrations-mostly from the social sciences-have stressed the importance of discretion for making law work (see Eule et al. 2019: 86, 105; Pratt 1999; Pratt and Sossin 2009). Discretion is seen as necessary for adapting the rules of law to individual cases (Pratt and Sossin 2009: 303; see also Lipsky 2010; Maynard-Moody and Musheno 2003). By arguing that discretion is indispensable for making law work, these scholars have, therefore, challenged the negative view on discretion held by classical legal scholars such as Albert Dicey (1982 [1885]). According to Anna Pratt and Lorne Sossin (2009), this "conventional view on discretion" understood discretion as something negative; as something that needed to be curbed as much as possible or even eliminated altogether, for instance through establishing new legal rules or control mechanisms (see also Liodden 2016: 69). Furthermore, these "newer" approaches have also challenged the quasi antagonistic relationship between law and discretion conveyed by the "conventional view", which held that "where the law ends, discretion begins" (Pratt and Sossin 2009: 302). ${ }^{3}$ Yet, I argue that depending on how discretion is conceptualised, some authors nevertheless continue to (implicitly) reproduce the binary between law and discretion. Hence, Tobias Eule, for example, by drawing on Michael Lipsky, defines discretion as something which exists in so-called "grey-zones", zones in which decision-makers are "not bound by a rule" (2014: 57; see also Lipsky 2010: 14-15). Thus, even if such practices are seen to make law work, the binary distinction still prevails.

When we talk about "discretion" what do we mean? I can identify three distinct meanings which are mainly ascribed to discretion in social science literature. In the first, discretion seems to equate with room for manoeuvre. It refers both to the leeway which street-level bureaucrats have in dealing with

\footnotetext{
${ }^{3}$ The latter understanding is nicely exemplified by Ronald Dworkin's famous analogy of the doughnut. "Discretion, like the hole in a doughnut", Dworkin writes, "does not exist except as an area left open by a surrounding belt of restriction" (1977: 31).
} 
cases, and to their obligation to make decisions. Thus, it is up to decisionmakers to decide which rules to "apply" in specific situations as well as when to "apply" certain rules and when not to. This view is conveyed by Tobias Eule et al. who write that

state officials always have room for manoeuvre and are thus confronted with the obligation to take decisions - however different these might be. The mobile police officer can decide whom to stop and search in the streets, which workplace to control and whom to take in for interrogation. The frontline caseworker can decide to detain or not to detain an individual lacking legal residency $[\ldots]$. The asylum centre staff member or detention officer can decide when and which disciplinary sanction to use against residents or detainees, and when to overlook infractions to the house code. (2019: 82)

In a second use, discretionary practices are understood not only as decision-makers' actions of choosing between different legal rules and deciding when (not) to "apply" them, but also as decision-makers' actions of interpreting legal rules when "applying" them to specific cases or situations (see Eckert 2020: 15-16; Hawkins 1992: 11; Liodden 2016: 69). In a third meaning, caseworkers' actions of "establishing the 'facts' of [...] [a] case" are also referred to as discretionary practices (Liodden 2016: 68; see also Galligan 1990: 35; Hawkins 1992: 35).

These understandings differ from the term's "formal" definition in Swiss law. Thus, the Swiss Civil Code stipulates that "[w]here the law confers discretion on the court or makes reference to an assessment of the circumstances or to good cause, the court must reach its decision in accordance with the principles of justice and equity" (art. 4, Swiss Civil Code). ${ }^{4}$ Discretion (Ermessen) in Swiss jurisdiction is, therefore, understood as a power given by written legislation and seen to exist only then. Contrarily, in my understanding-which draws on the work of the above-mentioned authors-discretion inevitably forms part of law and decision-making in legal procedures, whether it is explicitly stated as such in the written legal text or not (see also Heyman 2009: 367). Furthermore, I make use of the term discretion regardless of whether decision-makers themselves feel that they have discretion for taking decisions or not.

If we look finally at the etymology, as Tone Liodden shows, discretion "stems from the Latin word 'discretionem' [...] meaning 'the power

\footnotetext{
${ }^{4}$ Similar definitions of discretion also exist in other civil law jurisdictions (see Eule 2014: 57; Eule et al. 2019: 87; Liodden 2016: 68). In common law systems, discretion seems to be more selfevidently accepted as playing a central part in decision-making.
} 
to make distinctions'" (2016: 75). This goes to the core of what administrative caseworkers do, for, as Don Handelman claims, " $[t]$ here is no bureaucracy without classification, without the invention of categories of inclusion and exclusion" (1995: 280; see also Handelman 2004). This also applies to the SEM where decision-makers' work comes down to assigning asylum claimants to one of four legal categories: refugee with asylum, refugee with temporary admission, non-refugee with temporary admission (mostly on the basis of so-called "humanitarian grounds") and non-refugee without temporary admission.

In contrast to the "conventional view on discretion", the focus in contemporary social science literature is mainly on the discretionary practices themselves rather than on "the restricting belt" governing them (see Liodden 2016: 69). Hence, as Anna Pratt and Lorne Sossin have noticed, social science studies have mainly focused on the "extra-legal' and 'non-legal' influences" on decision-making (2009: 304). In connection to this, Julia Eckert notes that some "ethnographic bottom-up perspectives on administration, policy or the state suffer from a lack of attention to the impact of formal rules and public ideologies - often due to the attempt to overcome reductionist top-down analyses that do not attend to variation in bureaucratic practice" (2020: 15-16, see also Fassin 2015: 5). This strong emphasis on variation in bureaucratic practice is something that also applies to the literature on asylum and migration administrations. Thus, much research is concerned with divergences between different asylum or migration administrations, different units within these administrations and, particularly, divergences between individual decision-makers (see, for instance, Anker 1991; Eule 2014; Fassin and Kobelinsky 2012; Hamlin 2014; Johannesson 2017; Miaz 2017; Ramji-Nogales et al. 2009; Rehaag 2012; Spirig 2018).

My point is not to argue that such divergences do not exist. Research has clearly shown that they do. Nevertheless, I argue that these divergences should not be overestimated or, more particularly, that we should be careful not to lose sight of the commonalities that exist. To give an example, some individual asylum caseworkers might be more readily inclined to believe asylum seekers' stories than others, generating diverging outcomes. However, my research has shown that even the decision-makers who are more inclined to believe asylum seekers—-the so-called "softies" in the SEM-still end up rejecting the majority of asylum applications they deal with on the grounds of non-credibility. Hence, I argue that it is these regularities that we should pay attention to, inquiring into the different factors that generate such patterns.

Focusing on divergences brings the danger of (implicitly) assigning an overly individualistic quality to discretionary practices. This also becomes 
apparent in the way the term discretion itself is sometimes conceptualised, as shown in the following statement by Tony Evans who writes that "[a]s a topic, discretion is concerned with the extent of freedom a worker can exercise in a specific context and the factors that give rise to this freedom in that context" (2010: 2). Similarly, Tobias Eule, referring to Norbert Cyrus and Dita Vogel (2003) as well as Anna Triandafyllidou (2003), describes discretionary practices as "deviant' techniques of individual practice" (2014: 57). With this book, I attempt to overcome this "individualist bent" (Eckert 2020: 9-10). My approach-similar to that of Julia Dahlvik (2018) and Tone Liodden (2016) — is, therefore, not only to study what caseworkers' discretionary practices are-thus, how caseworkers deal with their room for manoeuvre, interpret legal rules when "applying" them, assemble cases and produce the necessary "facts" for taking decisions-but also to analyse ethnographically the different factors that shape these discretionary practices. As I will show in this book, the concept of the institutional habitus provides a unique way of doing so by drawing attention to the unthinking, routine and self-evident actions and judgements of decision-makers and how they come to adopt such dispositions through institutional socialisation.

\section{Assessing Credibility in Asylum Procedures: A Subjective Matter?}

In turning now to assessing credibility, we can see that an individualistic quality is similarly ascribed to asylum decision-makers' practices by many of the critical studies on credibility determination in asylum procedures. Credibility determination plays a crucial role in asylum decision-making, since credibility constitutes a major precondition for being recognised as a refugee and receiving asylum. In Switzerland, the majority of asylum applicants are rejected not because their claims do not fulfil refugee status requirements, but rather because they are not perceived as being credible; a trend that has also been observed in other countries, such as France (Fassin 2013: 47; Probst 2012), Germany (Probst 2012) and the UK (Kelly 2012: 759). Because of the importance of credibility determination for asylum adjudication and the widespread tendency to reject the majority of asylum applications on the basis of non-credibility, credibility determination has attracted much scholarly attention. ${ }^{5}$ Scholars engage critically with credibility assessment

\footnotetext{
${ }^{5}$ Audrey Macklin (1998), for instance, has dealt with credibility assessment (practices) in Canada, Thomas Scheffer $(2001,2003)$ has done so in Germany, Nienke Doornbos (2005) and Thomas
} 
(practices), highlighting both the difficulty of taking decisions based on credibility, as well as the obstacles and injustices they generate for asylum seekers. Much critique has thereby been directed at the so-called "subjectivity" and "arbitrariness" of decision-makers' credibility assessments as well as at a caseworker's so-called common sense, their understanding of what constitutes normal or abnormal behaviour, and the role this has in credibility determinations (see Einhorn 2009; Goodwin-Gill 1996; Kagan 2003; Macklin 1998; Ramji-Nogales et al. 2009; Thomas 2009). ${ }^{6}$ By doing so, the problem of credibility assessment is often (implicitly) attributed to the individual decision-makers and/or to "the law" for leaving a loophole for subjective decision-making in the first place. This, I argue, leads to decision-makers' practices being attributed an individualist quality, which is a view that I critically engage with in this book (see also Eckert 2020). Thus, Michael Kagan, for instance, claims that "subjective assessments are highly personal to the decision-maker, dependent on personal judgement, perceptions and dispositions, and often lacking an articulated logic" (2003: 374). He criticises that these assessments are, therefore, "very difficult to review and are likely to be inconsistent from one decision-maker to another" (ibid.).

There appear to be two main reasons why much of the critique on credibility assessment practices in asylum procedures focuses on their so-called "subjectivity" and "arbitrariness". On the one hand, it has to do with the outcome orientation of many of these critical studies. Hence, many of the analyses are based on written asylum decisions, making it difficult to deduce

\footnotetext{
Spijkerboer $(2000,2005)$ in the Netherlands, Walter Kälin (1986), Olivia Le Fort (2013) as well as Alain Maillard and Christophe Tafelmacher (1999) in Switzerland, Anthony Good (2009, 2011), Jane Herlihy et al. (2010), Catriona Jarvis (2003), Olga Jubany (2011, 2017), Tobias Kelly (2011), Isabella Mighetto (2016), James Sweeney (2007) and Robert Thomas (2009) in the UK and Deborah Anker (1991), Bruce Einhorn (2009) and Michael Kagan (2003) in the USA. Furthermore, many authors dealing with asylum decision-making in general and especially asylum interviews also broach the subject of credibility (see, for instance, Blommaert 2001; Bohmer and Shuman 2008; Dahlvik 2018; Fresia et al. 2013; Poertner 2018; Probst 2012; Miaz 2017; Rousseau et al. 2002; Sbriccoli and Jacoviello 2011; Schneider and Wottrich 2017), as do authors dealing with particular problems applicants face when seeking asylum on the basis of sexual orientation (see, for instance, Jansen and Spijkerboer 2011; Johnson 2011; Markard and Adamietz 2011; O’Leary 2008; Spijkerboer 2013). Finally, there have also been evaluative studies on credibility assessment, for instance, the report "Breaking down the barriers" written by Heaven Crawley (1999) for the Immigration Law Practitioners' Association (ILPA), the UNHCR evaluation "Beyond Proof: Credibility Assessment in EU Asylum Systems" (2013) and the joint report by Amnesty International and Still Human Still Here "A question of credibility: Why so many initial asylum decisions are overturned on appeal in the UK" (2013).

${ }^{6}$ Other authors, however, take their analyses in different directions, focusing, for example, on communication problems in asylum interviews and the obstacles asylum seekers face when trying to successfully-meaning credibly—narrate their stories (see, for instance, Doornbos 2005; Good 2009, 2011; Kagan 2003; Kälin 1986) or on the particular standard of proof in asylum procedures and the way uncertainty is turned into legal certainty through the procedure (see Kelly 2011; Scheffer 2001, 2003).
} 
how decision-makers reached their decisions, as from the "outside" the outcomes of decision-making processes often seem very random and much of what plays into decision-making is not actually reflected in the written reasoning. 7 On the other hand, the critique of the "subjectivity" and "arbitrariness" of asylum, and particularly credibility decisions, may also derive from decision-makers' emic views on their own work. Thus, in my research I found that many decision-makers in the SEM themselves attach a "subjective" quality to their credibility determinations. This is expressed in the following statement made by a decision-maker whom I have called Denise ${ }^{8}$ :

The word 'credibility' already indicates that it's subjective. I have to believe something. [...] And precisely because it's subjective it's easier for me if I've seen [the applicant] myself. That doesn't necessary mean that the decision [I take] is then the correct one, but it makes it easier for me, because then, in addition, I have this personal impression. ${ }^{\text {? }}$

As Denise's statement hints at, this view that credibility determinations are, to some extent, always "subjective" is linked to the kind of knowledge that guides and enables credibility assessments, an issue I deal with in detail in Chapter 4. I was told by SEM decision-makers that their credibility assessments often started from a "feeling" or "intuition", a finding which is also shared by many other scholars working on asylum decision-making (see, for instance, Fassin and Kobelinsky 2012; Fassin 2013; Johannesson 2017; Jubany 2011, 2017; Kelly 2012; Macklin 1998; Miaz 2017; Thomas 2009). Such intuitive convictions are usually very difficult to articulate; decisionmakers—at least the experienced ones—mostly "just know" whether asylum seekers' statements are credible or not (see also Jubany 2017: 121, 183;

\footnotetext{
${ }^{7}$ There appear to be several reasons for this outcome orientation. First, access to asylum administrations in order to observe decision-makers' everyday practices is often very difficult —or even impossible - to achieve. Second, the outcome orientation of these critical studies seems to be linked to the authors' disciplinary backgrounds and their methodological approaches: many of the authors are legal scholars whose discussions are generally based on analyses of written legal documents. Third, many of the authors are mainly interested in what the outcomes of asylum decision-making mean for asylum seekers and what consequences they have for them rather than how these particular outcomes came into being.

${ }^{8}$ All the names I use in this book are pseudonyms. For reasons of anonymity I have randomly assigned "identification features" such as place of work, educational background and gender to my interaction partners as long as it did not lead to any distortions. Furthermore, as it is important that officials (especially those in higher hierarchical positions) do not recognise their co-workers (or employees), it was sometimes necessary for me to create more than one "fictional identity" out of one interaction partner. I have anonymised all the references I make to asylum seekers and other actors in this book (for instance when quoting field notes or documents from case files) in the same way. My interactions with decision-makers were in Swiss German, German and French. The translations of their statements in this book are mine.

${ }^{9}$ Denise, caseworker, headquarters, interview transcript, my own translation.
} 
Liodden 2016: 264-265). Hence, this is the "feeling" or intuitive knowledge that they refer to as being "subjective". My point is not to argue that an asylum narrative, that to one decision-maker "feels" credible, might not "feel" credible to someone else. Yet, an observation I made in the SEM was that the "feelings" that decision-makers referred to as "subjective" often closely resembled each other and were, at the same time, often quite different from mine, the researcher from "outside". This is also what Nora seems to be referring to in her statement (quoted at the beginning of this introduction) that she "knows" or can at least "imagine" what certain assessments mean for her experienced employees. Hence, I argue that it is crucial to study how such forms of "tacit knowledge", to use Michael Polanyi’s (1962 [1958], 1966) term, or "practical knowledge" in the words of Andreas Reckwitz (2003), develop, are acquired by decision-makers and are reaffirmed as well as transformed through their everyday practices. In order to do so, I propose the concept of the institutional habitus.

\section{The Institutional Habitus: A Brief Conceptual Introduction}

According to Loïc J.D. Wacquant, the main question practice theory deals with is: in the light of the regularities we observe in social life, what generates these patterns "[i]f external structures do not mechanically constrain action"? (1992: 18). It is precisely this question that interests me with regard to administrative work more generally, and asylum determination practices in the SEM more specifically. The answer to this question, according to Pierre Bourdieu, lies in the habitus. Bourdieu defines the habitus as a system of

durable, transposable dispositions, structured structures predisposed to function as structuring structures, that is, as principles which generate and organize practices and representations that can be objectively adapted to their outcomes without presupposing a conscious aiming at ends or an express mastery of the operations necessary in order to attain them. (1990: 53)

He argues that the habitus

is what makes it possible to produce an infinite number of practices that are relatively unpredictable [...] but also limited in their diversity. In short, being the product of a particular class of objective regularities, the habitus tends to generate all the 'reasonable', 'common sense' behaviours (and only these) which are possible within the limits of these regularities, and which are likely 
to be positively sanctioned because they are objectively adjusted to the logic characteristic of a particular field. (ibid.: 55-56)

For Bourdieu, the dispositions which constitute a habitus are shared by people belonging to the same social class or social collective. Thus, according to him, people from the same social background, who share certain experiences and histories, tend to have a similar habitus. This means that while the habitus operates from within individuals, it is not strictly individual (Wacquant 1992: 18). At the same time, the habitus does not work in a deterministic way (Hitchings 2012: 62). It is creative and inventive and can produce "an infinite number of practices" (Bourdieu 1990: 55). Yet, the practices a habitus generates will necessarily always fall within "the limits of its structures" (Wacquant 1992: 19).

I find the concept of habitus useful for understanding practices of decisionmaking in the SEM for three main reasons. First, because it allows us to analyse the "shared subjectivity" I encountered during fieldwork. This fits with what Bourdieu writes about the habitus when he states that " $t]$ o speak of habitus is to assert that the individual, and even the personal, the subjective, is social, collective. Habitus is socialized subjectivity" (Bourdieu and Wacquant 1992: 126). Second, the concept of habitus proves useful because it allows us to comprehend patterns in decision-making which cannot be explained with reference to explicit rules and informal norms. Thus, as Bourdieu writes, the practices the habitus generates are "[o]bjectively 'regulated' and 'regular' without being in any way the product of obedience to rules, they can be collectively orchestrated without being the product of the organizing action of a conductor" (1990: 53). One such pattern that I deal with in this book is the tendency to reject the majority of asylum applications on the basis of non-credibility; a pattern which has been referred to by many authors as the "culture of disbelief" (Anderson et al. 2014; Jubany 2017; Marfleet 2006), "suspicion" (Alpes and Spire 2014; Bohmer and Shuman 2008), "mistrust" (Griffiths 2012; Probst 2012) or "denial" (Souter 2011). The concept of the institutional habitus provides a way of understanding this pattern without reducing it to being the "mere" outcome of political instrumentality (of antiimmigration politics so to speak) or caseworkers' emotional detachment. The third reason for finding the concept of the institutional habitus useful for understanding practices of asylum decision-making is the importance it gives to the issue of belonging. Institutional belonging, both to the office as a whole as well as to individual divisions of the SEM, on the one hand, shapes what decision-makers come to perceive as their duties and what it means to professionally fulfil them, which, in turn, shapes their everyday practices (see also Affolter et al. 2019). On the other hand, institutional belonging is important 
because the institution becomes a site where experiences come to be shared and are collectively made.

In his work, Bourdieu mostly focuses on belonging in terms of people's social backgrounds and class. However, in "An Invitation to Reflexive Sociology" he also refers to bureaucracies as an example of a social collective. He claims that

social collectives such as bureaucracies have built-in propensities to perpetuate their being, something akin to a memory or a loyalty that is nothing other than the 'sum' of routines and conducts of agents who, relying on their know-how (métier), their habitus, engender [...] lines of action adapted to the situation such as their habitus inclines them to perceive it, thus tailor made (without being designed as such) to reproduce the structure of which their habitus is the product. (Bourdieu and Wacquant 1992: 139-140)

My conceptualisation of the institutional habitus builds on this understanding of bureaucratic organisations as self-perpetuating social collectives. I argue that, through belonging to and working in such organisations, caseworkers acquire specific dispositions which shape their everyday practices. These dispositions, in turn, are again shaped and reaffirmed by decisionmakers' everyday practices.

Instead of focusing on how SEM decision-makers' social backgrounds shape their dispositions to understand, judge and act, I mainly look at how these practices are shaped by decision-makers' belonging to the office and their experiences on the job. This is not to say that caseworkers' background does not have an influence on their everyday practices. The argument I make in this book is rather that their social backgrounds alone are not enough to explain why they do what they do. For this, we must study the professional values, pragmatic beliefs and (unthinking) routines that decision-makers pick up and come to incorporate through their institutional socialisation. Compared to Bourdieu's concept of habitus, my derivation of the concept is, therefore, less durable. I understand the institutional habitus as something that is acquired on the job, and possibly shed after leaving the institution.

Similar concepts have also been used by Didier Fassin as well as Maybritt Jill Alpes and Alexis Spire. The term Didier Fassin uses is that of the "professional habitus". However, he refers only very briefly to it in the introduction to "At the Heart of the State", where he argues that officials' "principles of justice [and] or order" as well as "the values of the common good and public service" are the products of officials' professional habitus (2015: 6). For Maybritt Jill Alpes and Alexis Spire, the "bureaucratic habitus" constitutes 
one of the principle concepts which they introduce in their article "Dealing with Law in Migration Control" (2014). Like me-and as Didier Fassin also seems to imply - the authors argue that it is the habitus that "significantly shapes [...] [caseworkers'] interpretations of the legal frameworks" (2014: 263). However, there are two important differences between their usage of the term bureaucratic habitus and my conceptualisation of the institutional habitus. First, for Alpes and Spire, the bureaucratic habitus "encompasses a set of norms shared by other agents involved in migration control" (ibid.). Hence, they understand it as a set of norms that is shared by all agents working in the field of migration control. In this regard, I conceptualise the institutional habitus in a narrower sense, namely as the set of dispositions shared within an organisation-or possibly even within different parts of an organisation. However, this does not mean that I dismiss the impact of the broader ideological environment(s) within which asylum decision-making takes place, but rather that I am interested in how certain ideological values become incorporated by caseworkers working inside these particular organisations (see also Dahlvik 2018; Jubany 2017). Second, in my understanding, the institutional habitus is mainly an analytical term that can be used to describe the assemblage of dispositions which shape what caseworkers do, think and feel. Alpes and Spire, in turn, refer to the bureaucratic habitus in order to describe specific dispositions they encountered during their fieldwork in French consulates, namely the "culture of suspicion" (ibid.: 269) as well as-connected to this-caseworkers' "concern to combat fraud and to defend state interests" (ibid.: 267). This is very similar to what I encountered in the SEM (see Chapter 6). However, in my understanding, the institutional habitus is not limited to these dispositions, but also encompasses other-to some extent even contradicting-dispositions. Furthermore, with this book I aim to show that the "concern to combat fraud and to defend state interests" (ibid.) does not only guide and shape caseworkers' actions, but to also show that the very idea that professionally carrying out one's job means combatting fraud and defending the state's interests is continuously reaffirmed and reproduced through everyday practice in these administrations.

\section{Outline of the Book}

Chapters 2 and 3 set the scene for the three main analytical chapters of this book. Chapter 2 provides a methodological note on how I went about studying everyday decision-making practices in the SEM. It discusses the challenges I faced during my research and how I dealt with them, as well 
as the methodological limits of this study. Furthermore, I engage with what it means methodologically, to study everyday practice(s) from a practice theoretical perspective.

Following this, Chapter 3 offers a description of the Swiss asylum procedure. It discusses the history of asylum politics, policies, law and the first-instance asylum administration in Switzerland since the 1950s, and contextualises the developments within broader trends in the Global North. The chapter also introduces readers to the organisational structure of the SEM as it existed until 2019, to how different tasks are organised within the hierarchical organisation of the SEM, to the main elements of asylum law that structure SEM officials' decision-making practices and to the particular standard of proof in refugee status determination.

The three main analytical chapters of this book deal with the "shared practices" of decision-making. They shed light on what these practices are, and describe the processes whereby these practices become shared. Although each in a different way, the three main chapters are concerned with: how decision-makers' discretionary practices are shaped and structured; the role the institutional habitus plays; what constitutes this institutional habitus; how decision-makers develop such an institutional habitus on the job; and finally, how the institutional habitus is reaffirmed through everyday practice.

Chapter 4 traces the processes of how asylum decisions are produced. It analyses how asylum caseworkers attempt to overcome the uncertainties inherent in refugee status - and particularly credibility_-determination, and the role different types of knowledge thereby play. Decision-making practice, it argues, is fundamentally a "knowledge-based activity" (Dahlvik 2018: 57). The chapter highlights the important role implicit practical knowledge-or "gut feeling" - as well as the act of credibility determination itself play in generating decisional certainty for categorising asylum seekers into one of four legal categories: refugee with asylum, refugee with temporary admission, non-refugee with temporary admission and non-refugee without temporary admission.

The fifth chapter explores how asylum caseworkers are socialised on the job and acquire an institutional habitus. It shows how decision-makers learn what appropriate and inappropriate behaviours are and acquire the necessary knowledge and skills for carrying out their job. I argue that caseworkers' desire and need to fit into "the office" (or parts of it) and to be considered good and professional decision-makers, as well as the pressure decisionmakers experience from their peers, superiors, but also from politics and 
the media all play an important role in shaping decision-makers' everyday practices.

In Chapter 6, I examine the norms and values which lie at the heart of SEM officials' day-to-day decision-making, showing what it means to be a good and professional decision-maker in the SEM. The chapter brings to light two substantial goals of the asylum administration: that of protecting the abstract noble value of asylum and that of protecting "national interests" through keeping numbers low: both of people applying for asylum and of people being granted the right to reside in Switzerland. The chapter, thereby, shows how the ethics and ethos of the office shape what decision-makers do and how certain practices become normal and self-evident.

Finally, in the conclusion, I bring together the discussions of the different chapters of this book to show how normative, structural and regulatory constraints and the institutional habitus constitute each other; the latter through the practices it generates. By doing so, I show how disbelief becomes normalised in the office. I also discuss what lessons can be taken from the case study of this book, towards a more general understanding of bureaucratic administrations.

\section{References}

Affolter, Laura, Jonathan Miaz, and Ephraim Poertner. 2019. "Taking the 'Just' Decision: Caseworkers and Their Communities of Interpretation in the Swiss Asylum Office." In Asylum Determination in Europe: Ethnographic Perspectives, edited by Nick Gill, and Anthony Good, 263-284. Cham: Palgrave Macmillan. Alpes, Maybritt Jill, and Alexis Spire. 2014. "Dealing with Law in Migration Control: The Powers of Street-Level Bureaucrats at French Consulates." Social \& Legal Studies 23 (2): 261-274. https://journals.sagepub.com/doi/10.1177/096 4663913510927.

Amnesty International/Still Human Still Here. 2013. "A Question of Credibility: Why so Many Initial Asylum Decisions Are Overturned on Appeal in the UK." http://www.refworld.org/docid/518120c64.html, last accessed February 3, 2020. Anderson, Jessica, Jeannine Hollaus, Annelisa Lindsay, and Collin Williamson. 2014. The Culture of Disbelief: An Ethnographic Approach to Understanding an Under-Theorised Concept in the UK Asylum System. Working Paper Series No. 102. Oxford: Refugee Studies Centre. https://www.rsc.ox.ac.uk/files/files-1/wp102-cul ture-of-disbelief-2014.pdf, last accessed February 3, 2020. 
Anker, Deborah. 1991. "Determining Asylum Claims in the United States: An Empirical Case Study.” http://repository.forcedmigration.org/show_metadata.jsp? pid=fmo:709, last accessed February 3, 2020.

Beek, Jan. 2016. Producing Stateness: Police Work in Ghana. Boston: Brill.

von Benda-Beckmann, Franz. 1991. "Pak Dusa's Law: Thoughts on Legal Knowledge and Power." In Ethnologie im Widerstreit, edited by Eberhard Berg, Jutta Lauth, and Andreas Wimmer, 215-227. München: Trickster.

Bierschenk, Thomas, and Jean-Pierre Olivier de Sardan. 2014. "Studying the Dynamics of African Bureaucracies: An Introduction to States at Work." In States at Work: Dynamics of African Bureaucracies, edited by Thomas Bierschenk, and Jean-Pierre Olivier de Sardan, 1-33. Leiden, Boston: Brill.

Blommaert, Jan. 2001. "Investigating Narrative Inequality: African Asylum Seekers' Stories in Belgium.” Discourse \& Society 12 (4): 413-449. https://doi.org/10. 1177/0957926501012004002.

Bohmer, Carol, and Amy Shuman. 2008. Rejecting Refugees: Political Asylum in the 21st Century. London: Routledge.

Bourdieu, Pierre. 1976. Entwurf einer Theorie der Praxis auf der ethnologischen Grundlage der kabylischen Gesellschaft. Frankfurt am Main: Suhrkamp.

Bourdieu, Pierre. 1990. The Logic of Practice. Translated by Richard Nice. Stanford: Stanford University Press.

Bourdieu, Pierre, and Loïc J. D. Wacquant. 1992. "The Purpose of Reflexive Sociology (The Chicago Workshop).” In An Invitation to Reflexive Sociology, edited by Pierre Bourdieu, and Loïc J. D. Wacquant, 61-215. Cambridge: Polity Press.

Brodkin, Evelyn Z. 2011. "Policy Work: Street-Level Organizations Under New Managerialism." Journal of Public Administration Research and Theory 21 (Supplement 2): 253-277. https://doi.org/10.1093/jopart/muq093.

Brodkin, Evelyn Z. 2012. "Reflections on Street-Level Bureaucracy: Past, Present, and Future." Public Administration Review 72 (6): 940-949. https://doi.org/10. 1111/j.1540-6210.2012.02657.x.

Calavita, Kitty. 1992. Inside the State: The Bracero Program, Immigration, and the I.N.S. New York: Routledge.

Calavita, Kitty. 2005. "Law, Citizenship, and the Construction of (Some) Immigrant 'Others”. Law \& Social Inquiry 30 (2): 401-420. https://doi.org/10.1111/ j.1747-4469.2005.tb01017.x.

Crawley, Heaven. 1999. Breaking Down the Barriers: A Report on the Conduct of Asylum Interviews at Ports. London: Immigration Law Practitioners' Association (ILPA).

Cyrus, Norbert, and Dita Vogel. 2003. "Work-Permit Decisions in the German Labour Administration: An Exploration of the Implementation Process." Journal of Ethnic and Migration Studies 29 (2): 225-256. https://doi.org/10.1080/136 9183032000079602. 
Dahlvik, Julia. 2018. Inside Asylum Bureaucracy: Organizing Refugee Status Determination in Austria. IMISCOE Research Series. Cham: Springer.

Dicey, Albert V. 1982 (1885). Introduction to the Study of the Law of the Constitution. Indianapolis: Liberty Classics.

Doornbos, Nienke. 2005. "On Being Heard in Asylum Cases: Evidentiary Assessment through Asylum Interviews." In Proof, Evidentiary Assessment and Credibility in Asylum Procedures, edited by Gregor Noll, 103-122. Leiden: Martinus Nijhoff.

Downs, Anthony. 1967. Inside Bureaucracy. Boston: Little, Brown and Company.

Dworkin, Ronald. 1977. Taking Rights Seriously. Cambridge: Harvard University Press.

Eckert, Julia. 2020. "The Office: Ethos and Ethics in Migration Bureaucracies." In The Bureaucratic Production of Difference, edited by Julia Eckert, 7-26. Bielefeld: transcript.

Eckert, Julia, Andrea Behrends, and Andreas Dafinger. 2012. "Governance-And the State: An Anthropological Approach." Ethnoscripts 14 (1): 14-34.

Eckert, Julia, Zerrin Özlem Biner, Brian Donahoe, and Christian Strümpell. 2012. "Introduction: Law's Travels and Transformations." In Law Against the State: Ethnographic Forays into Law's Transformations, edited by Julia Eckert, Brian Donahoe, Christian Strümpell, and Zerrin Özlem Biner, 1-22. Cambridge: Cambridge University Press.

Einhorn, Bruce J. 2009. "Consistency, Credibility, and Culture." In Refugee Roulette: Disparities in Asylum Adjudication and Proposals for Return, edited by Jaya RamjiNogales, Andrew I. Schoenholtz, and Philip G. Schrag, 187-201. New York: New York University Press.

Eule, Tobias G. 2014. Inside Immigration Law. Migration Management and Policy Application in Germany. Farnham: Ashgate.

Eule, Tobias G., Lisa Marie Borrelli, Annika Lindberg, and Anna Wyss. 2019. Migrants Before the Law: Contested Migration Control in Europe. Cham: Palgrave Macmillan.

Evans, Tony. 2010. Professional Discretion in Welfare Services. Farnham: Ashgate.

Fassin, Didier. 2013. "The Precarious Truth of Asylum.” Public Culture 25 (1): 39-63. https://doi.org/10.1215/08992363-1890459.

Fassin, Didier. 2015. "Introduction: Governing Precarity." In At the Heart of the State: The Moral World of Institutions, edited by Didier Fassin, 1-11. London: Pluto Press.

Fassin, Didier, and Carolina Kobelinsky. 2012. "How Asylum Claims Are Adjudicated: The Institution as a Moral Agent." Revue française de sociologie 53 (4): 444-472. https://doi.org/10.3917/rfs.534.0657.

Fresia, Marion, David Bozzini, and Alice Sala. 2013. Les rouages de l'asile en Suisse: Regards ethnographiques sur une procédure administrative. Etudes du SFM 62. Neuchâtel: SFM. 
Fuglerud, Oivind. 2004. "Constructing Exclusion: The Micro-Sociology of an Immigration Department." Social Anthropology 12 (1): 25-40. https://doi.org/ 10.1111/j.1469-8676.2004.tb00088.x.

Galligan, Denis James. 1990. Discretionary Powers: A Legal Study of Official Discretion. Oxford: Clarendon Press.

Gill, Nick, and Anthony Good, eds. 2019. Asylum Determination in Europe. Ethnographic Perspectives. Cham: Palgrave Macmillan.

Good, Anthony. 2009. "The Taking and Making of Asylum Claims: Credibility Assessment in the British Asylum Courts." http://www.sps.ed.ac.uk/_data/ass ets/pdf_file/0014/31154/GoodSOAS.pdf, last accessed February 3, 2020.

Good, Anthony. 2011. "Witness Statement and Credibility Assessments in the British Asylum Courts." In Cultural Expertise and Litigation, edited by Livia Holden, 94-122. Abingdon, New York: Routledge.

Goodwin-Gill, Guy S. 1996. The Refugee in International Law. Second Edition. Oxford: Clarendon Press.

Griffiths, Melanie. 2012. "Vile Liars and Truth Distorters': Truth, Trust and the Asylum System.” Anthropology Today 28 (5): 8-12. https://doi.org/10.1111/j. 1467-8322.2012.00896.x.

Gupta, Akhil. 1995. "Blurred Boundaries: The Discourse of Corruption, the Culture of Politics, and the Imagined State." American Ethnologist 22 (2): 375-402. https://doi.org/10.1525/ae.1995.22.2.02a00090.

Hamlin, Rebecca. 2014. Let Me Be a Refugee: Administrative Justice and the Politics of Asylum in the United States, Canada, and Australia. Oxford: Oxford University Press.

Handelman, Don. 1995. "Comments on 'Putting Power in the Anthropology of Bureaucracy: The Immigrations and Naturalization Service at the Mexico-United States Border' by Josiah McC. Heyman.” Current Anthropology 36 (2): 280-281. https://doi.org/10.1086/204354.

Handelman, Don. 2004. Nationalism and the Israeli State: Bureaucratic Logic in Public Events. New York: Berg.

Hawkins, Keith, ed. 1992. The Uses of Discretion. Oxford: Clarendon Press.

Herlihy, Jane, Kate Gleeson, and Stuart Turner. 2010. "What Assumptions about Human Behaviours Underlie Asylum Judgements?" International Journal of Refugee Law 22 (3): 351-366. https://doi.org/10.1093/ijrl/eeq027.

Heyman, Josiah McC. 1995. "Putting Power in the Anthropology of Bureaucracy: The Immigration and Naturalization Service at the Mexico-United States Border." Current Anthropology 36 (2): 261-187. https://doi.org/10.1086/ 204354.

Heyman, Josiah McC. 2004. "The Anthropology of Power-Wielding Bureaucracies." Human Organization 63 (4): 487-500. https://doi.org/10.17730/humo. 63.4.m9phulu49a1l2dep. 
Heyman, Josiah McC. 2009. "Trust, Privilege, and Discretion in the Governance of US Borderlands with Mexico." Canadian Journal of Law and Society 24 (3): 367-390. https://doi.org/10.1017/S0829320100010085.

Hitchings, Russel. 2012. "People Can Talk About Their Practices." Area 44 (1): 61-67. https://doi.org/10.1111/j.1475-4762.2011.01060.x.

Jansen, Sabine, and Thomas Spijkerboer. 2011. "Fleeing Homophobia: Asylum Claims Related to Sexual Orientation and Gender Identity in the EU." Coc Nederlands/VU University Amsterdam. https://papers.ssrn.com/sol3/papers.cfm? abstract_id=2097783, last accessed February 3, 2020.

Jarvis, Catriona. 2003. "The Judge as Juror Revisited." Immigration Law Digest (Winter): 16-31.

Johannesson, Livia. 2017. In Courts We Trust: Administrative Justice in Swedish Migration Courts. Stockholm University. http://www.diva-portal.org/smash/get/ diva2:1072557/FULLTEXT01.pdf, last accessed February 3, 2020.

Johnson, Toni A. M. 2011. "On Silence, Sexuality and Skeletons: Reconceptualizing Narrative in Asylum Hearings." Social \& Legal Studies 20 (1): 57-78. https:// doi.org/10.1177/0964663910391205.

Jubany, Olga. 2011. "Constructing Truths in a Culture of Disbelief: Understanding Asylum Screening from Within.” International Sociology 26 (1): 74-94. https:// doi.org/10.1177/0268580910380978.

Jubany, Olga. 2017. Screening Asylum in a Culture of Disbelief: Truths, Denials and Sceptical Borders. Cham: Palgrave Macmillan.

Kagan, Michael. 2003. "Is Truth in the Eye of the Beholder? Objective Credibility Assessment in Refugee Status Determination." Georgetown Immigration Law Journal 17 (3): 367-415. https://scholars.law.unlv.edu/facpub/633, last accessed February 3, 2020.

Kälin, Walter. 1986. "Troubled Communication: Cross-Cultural Misunderstandings in the Asylum-Hearing." International Migration Review 20 (2): 230-241. https://doi.org/10.1177/019791838602000206.

Kelly, Tobias. 2011. "The Legalization of Human Rights and the Protection of Torture Survivors: Asylum, Evidence and Disbelief." In Are Human Rights for Migrants? Critical Reflections on the Status of Irregular Migrants in Europe and the United States, edited by Marie-Bénédicte Dembour, and Tobias Kelly, 1-22. New York: Routledge.

Kelly, Tobias. 2012. "Sympathy and Suspicion: Torture, Asylum, and Humanity." Journal of the Royal Anthropological Institute 18 (4): 753-768. https://doi.org/10. 1111/j.1467-9655.2012.01790.x.

Kobelinsky, Carolina. 2015. "In Search of Truth: How Asylum Applications Are Adjudicated." In At the Heart of the State: The Moral World of Institutions, edited by Didier Fassin, 67-92. London: Pluto Press.

Lahusen, Christian, and Stephanie Schneider, eds. 2017. Asyl verwalten. Zur bürokratischen Bearbeitung eines gesellschaftlichen Problems. Bielefeld: transcript. 
Le Fort, Olivia. 2013. "Des guidelines pour mieux circonscrire la notion de vraisemblance en matière d'asile." Jusletter 18: 1-9.

Liodden, Tone Maia. 2016. "The Burdens of Discretion. Managing Uncertainty in the Asylum Bureaucracy." PhD diss. (unpublished), University of Oslo.

Lipsky, Michael. 2010. Street-Level Bureaucracy, 30th Anniversary Edition: Dilemmas of the Individual in Public Service. New York: Russell Sage Foundation.

Macklin, Audrey. 1998. "Truth and Consequences: Credibility Determination in the Refugee Context." Conference Paper. Ottawa: International Association of Refugee Law Judges. http://refugeestudies.org/UNHCR/97\%20-\%20Truth\% 20 and $\% 20$ Consequences. $\% 20$ Credibility $\% 20$ Determination $\% 20$ in $\% 20$ Refu gee $\% 20$ Context.\%20by\%20Audrey\%20Macklin.pdf, last accessed February 3, 2020.

Maillard, Alain, and Christophe Tafelmacher. 1999. "Faux réfugiés"? La politique Suisse de dissauasion d'asile, 1979-1999. Lausanne: Éditions d'en bas.

Marfleet, Philip. 2006. Refugees in a Global Era. Basingstoke: Palgrave.

Markard, Nora, and Laura Adamietz. 2011. "Keep it in the Closet? Flüchtlingsanerkennung wegen Homosexualität auf dem Prüfstand.” Kritische Justiz 44 (3): 294-302.

Maynard-Moody, Steven, and Michael Musheno. 2003. Cops, Teachers, Conselors: Stories from the Front Lines of Public Service. Ann Arbor: University of Michigan Press.

Miaz, Jonathan. 2017. "Politique d'asile et sophistication du droit: Pratiques administratives et défense juridique des migrants en Suisse (1981-2015).” $\mathrm{PhD}$ diss. (unpublished), University of Lausanne and University of Strasbourg.

Mighetto, Isabella. 2016. "The Contingency of Credibility: Gender-Related Persecution, Traumatic Memory and Home Office Interviews." SOAS Law Journal 3: 1-37.

Moore, Sally Falk. 1978. Law as Process: An Anthropological Approach. London, Henley: Routledge \& Kegan Paul.

Mountz, Alison. 2010. Seeking Asylum: Human Smuggling and Bureaucracy at the Border. Minneapolis: University of Minnesota Press.

O’Leary, Barry. 2008. "We Cannot Claim Any Particular Knowledge of the Ways of Homosexuals, Still Less of Iranian Homosexuals...': The Particular Problems Facing Those Who Seek Asylum on the Basis of Their Sexual Identity." Feminist Legal Studies 16 (1): 87-95. https://doi.org/10.1007/s10691-007-9080-z.

Poertner, Ephraim. 2017. "Governing Asylum through Configurations of Productivity and Deterrence: Effects on the Spatiotemporal Trajectories of Cases in Switzerland." Geoforum 78: 12-21. https://doi.org/10.1016/j.geoforum.2016. 11.004.

Poertner, Ephraim. 2018. "Re-cording Lives: Governing Asylum in Switzerland and the Need to Resolve." PhD diss. (unpublished), University of Zurich.

Polanyi, Michael. 1962 (1958). Personal Knowledge: Towards a Post-Critical Philosophy. London: Routledge.

Polanyi, Michael. 1966. The Tacit Dimension. Chicago: University of Chicago Press. 
Pratt, Anna C. 1999. "Dunking the Doughnut: Discretionary Power, Law and the Administration of the Canadian Immigration Act." Social \& Legal Studies 8 (2): 199-226. https://doi.org/10.1177/096466399900800203.

Pratt, Anna, and Lorne Sossin. 2009. "A Brief Introduction of the Puzzle of Discretion." Canadian Journal of Law and Society 24 (3): 301-312. https://doi.org/10. 1017/S082932010001005X.

Probst, Johanna. 2012. Instruire la demande d'asile: étude comparative du processus décisionnel au sein de l'administration allemande et française. Science politique, Université de Strasbourg. https://tel.archives-ouvertes.fr/tel-00985215/doc ument, last accessed February 3, 2020.

Ramji-Nogales, Jaya, Andrew I. Schoenholtz, and Philip G. Schrag, eds. 2009. Refugee Roulette: Disparities in Asylum Adjudication and Proposals for Reform. New York: New York University Press.

Reckwitz, Andreas. 2003. "Grundelemente einer Theorie sozialer Praktiken: Eine sozialtheoretische Perspektive." Zeitschrift für Soziologie 32 (4): 282-301.

Rehaag, Sean. 2012. "Judicial Review of Refugee Determinations: The Luck of the Draw?” Queen's Law Journal 38 (1): 1-58. https://dx.doi.org/10.2139/ssrn.202 7517.

Rousseau, Cécile, François Crépeau, Patricia Foxen, and France Houle. 2002. "The Complexity of Determining Refugeehood: A Multidisciplinary Analysis of the Decision-Making Process of the Canadian Immigration and Refugee Board." Journal of Refugee Studies 15 (1): 43-70. https://doi.org/10.1093/jrs/15.1.43.

Sarat, Austin. 2007. "Vitality Amidst Fragmentation: On the Emergence of Postrealist Law and Society Scholarship." In The Blackwell Companion to Law and Society. Third Edition, edited by Austin Sarat, 1-11. Malden: Blackwell.

Sbriccoli, Tommaso, and Stefano Jacoviello. 2011. "The Case of S: Elaborating the 'Right' Narrative to Fit Normative/Political Expectations in Asylum Procedure in Italy." In Cultural Expertise and Litigation, edited by Livia Holden, 172-194. Abingdon, New York: Routledge.

Scheffer, Thomas. 2001. Asylgewährung: Eine ethnographische Analyse des deutschen Asylverfahrens. Stuttgart: Lucius \& Lucius.

Scheffer, Thomas. 2003. "Kritik der Urteilskraft: Wie die Asylprüfung Unentscheidbares in Entscheidbares überführt." In Migration steuern und verwalten: Deutschland vom späten 19. Jahrhundert bis zur Gegenwart, edited by Jochen Oltmer, 423-458. Göttingen: Vandenhoeck \& Ruprecht.

Schneider, Stephanie, and Kristina Wottrich. 2017. “'Ohne'ne ordentliche Anhörung kann ich keine ordentliche Entscheidung machen ... ': Zur Organisation von Anhörungen in deutschen und schwedischen Asylbehörden.” In Asyl verwalten: Zur bürokratischen Bearbeitung eines gesellschaftlichen Problems, edited by Christian Lahusen, and Stephanie Schneider, 81-115. Bielefeld: transcript.

Sharma, Aradhana, and Akhil Gupta, eds. 2006. The Anthropology of the State: A Reader. Malden: Blackwell. 
Shore, Cris, and Susan Wright. 2011. "Conceptualising Policy: Technologies of Governance and the Politics of Visibility." In Policy Worlds: Anthropology and the Analysis of Contemporary Power, edited by Cris Shore, Susan Wright, and Davide Però, 1-25. New York: Berghahn Books.

Souter, James. 2011. "A Culture of Disbelief or Denial? Critiquing Refugee Status Determination in the United Kingdom." Oxford Monitor of Forced Migration 1 (1): 48-59.

Spijkerboer, Thomas. 2000. Gender and Refugee Status. Aldershot: Ashgate.

Spijkerboer, Thomas. 2005. "Stereotyping and Acceleration: Gender, Procedural Acceleration and Marginalised Judicial Review in the Dutch Asylum System." In Proof, Evidentiary Assessment and Credibility in Asylum Procedures, edited by Gregor Noll, 67-102. Leiden: Martinus Nijhoff.

Spijkerboer, Thomas, ed. 2013. Fleeing Homophobia: Sexual Orientation, Gender Identity and Asylum. Abingdon: Routledge.

Spirig, Judith. 2018. Like Cases Alike or Asylum Lottery? Judicial Decision Making at the Swiss Administrative Court. University of Zurich. https://doi.org/10.5167/ uzh-157718.

Sweeney, James A. 2007. "The 'Lure' of Facts in Asylum Appeals: Critiquing the Practice of Judges." In Applying Theory to Policy and Practice: Issues for Critical Reflection, edited by Steven R. Smith, 19-35. Hampshire: Ashgate.

Swiss Civil Code, of 10 December 1907 (Status as of 1 January 2019). 210.

Terdiman, Richard. 1987. "The Force of Law: Toward a Sociology of the Juridical Field by Pierre Bourdieu: Translator's Introduction." Hastings Law Journal 38 (5): 805-853.

Thomas, Robert. 2009. "Refugee Roulette: A UK Perspective." In Refugee Roulette: Disparities in Asylum Adjudication and Proposals for Return, edited by Jaya RamjiNogales, Andrew I. Schoenholtz, and Philip G. Schrag, 164-186. New York: New York University Press.

Tomkinson, Sule B. 2018. "Who Are You Afraid of and Why? Inside the Black Box of Refugee Tribunals." Canadian Public Administration 61 (2): 184-204. https:// doi.org/10.1111/capa.12275.

Triandafyllidou, Anna. 2003. "Immigration Policy Implementation in Italy: Organisational Culture, Identity Processes and Labour Market Control." Journal of Ethnic and Migration Studies 29 (2): 257-298. https://doi.org/10.1080/136918 3032000079611.

United Nations High Commissioner for Refugees. 2013. Beyond Proof: Credibility Assessment in EU Asylum Systems. Brussels: UNHCR. http://www.unhcr.org/51a 8a08a9.pdf, last accessed February 3, 2020.

Wacquant, Loïc J. D. 1992. "Toward a Social Praxeology: The Structure and Logic of Bourdieu's Sociology." In An Invitation to Reflexive Sociology, edited by Pierre Bourdieu, and Loïc J. D. Wacquant, 1-59. Cambridge: Polity Press.

Wagenaar, Hendrik. 2004. "Knowing' the Rules: Administrative Work as Practice." Public Administration Review 64 (6): 643-656. https://doi.org/10.1111/j.15406210.2004.00412.x. 
Weber, Max. 2013 (1978). Economy and Society. Edited by Guenther Roth and Claus Wittich. Berkeley: University of California Press.

Wedel, Janine R., Cris Shore, Gregory Feldman, and Stacey Lathrop. 2005. "Toward an Anthropology of Public Policy." Annals of the American Academy of Political and Social Science 600 (1): 30-51. https://doi.org/10.1177/0002716205276734.

Open Access This chapter is licensed under the terms of the Creative Commons Attribution 4.0 International License (http://creativecommons.org/licenses/by/4.0/), which permits use, sharing, adaptation, distribution and reproduction in any medium or format, as long as you give appropriate credit to the original author(s) and the source, provide a link to the Creative Commons license and indicate if changes were made.

The images or other third party material in this chapter are included in the chapter's Creative Commons license, unless indicated otherwise in a credit line to the material. If material is not included in the chapter's Creative Commons license and your intended use is not permitted by statutory regulation or exceeds the permitted use, you will need to obtain permission directly from the copyright holder.

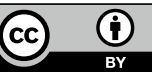

